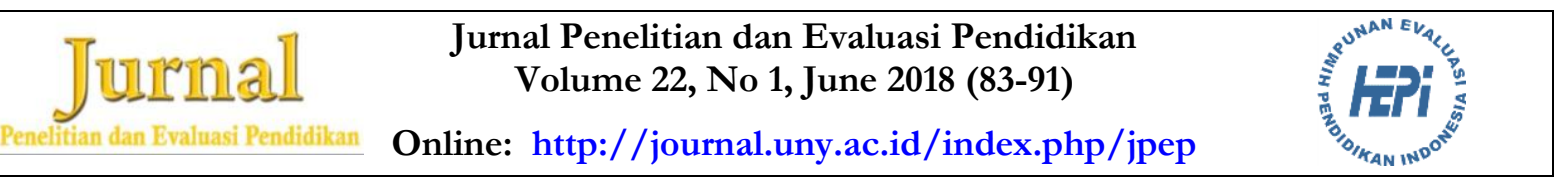

\title{
NILAI KEUTAMAAN PENGETAHUAN DAN KEBIJAKSANAAN DALAM KONTEKS PENDIDIKAN KARAKTER BANGSA
}

\author{
Wabyu Hidayat $^{1}$ *, Jamil Bin Abmad ${ }^{2}$, Mohd. Isa Bin Hamzah ${ }^{2}$ \\ ${ }^{1}$ Universiti Kebangsaan Malaysia/IAIN Parepare \\ ${ }^{2}$ Universiti Kebangsaan Malaysia \\ ${ }^{1}$ Jl. Amal Bhakti No.8, Bukit Harapan, Soreang, Parepare, Sulawesi Selatan 91131, Indonesia/ \\ 43600 Bangi, Selangor, Malaysia \\ ${ }^{2} 43600$ Bangi, Selangor, Malaysia \\ * Corresponding Author. Email: wahyuukm82@gmail.com
}

\begin{abstract}
Abstrak
Pengetahuan dan kebijaksanaan adalah nilai keutamaan tentang fungsi kognitif. Pengetahuan dapat diimplementasikan dalam peningkatan kualitas hidup manusia. Dalam konteks pendidikan karakter bangsa, nilai kreatif, rasa ingin tahu, dan gemar membaca merupakan faktor kekuatan karakter yang membangun nilai keutamaan pengetahuan dan kebijaksanaan. Kajian ini bertujuan untuk memeriksa struktur nilai-nilai karakter bangsa yang menjadi bagian dari nilai keutamaan pengetahuan dan kebijaksanaan. Penelitian ini melibatkan 780 responden siswa SMA. Dapatan kajian menunjukkan bahwa terbentuk tiga faktor kekuatan karakter yaitu kreatif, rasa ingin tahu, dan gemar membaca. Ketiga faktor tersebut merupakan faktor yang dapat membangun nilai keutamaan pengetahuan dan kebijaksanaan.
\end{abstract}

Kata kunci: pengetahuan dan kebijaksanaan, pendidikan karakter bangsa

\section{THE EXCELLENCE VALUES OF KNOWLEDGE AND WISDOM IN NATIONAL CHARACTER EDUCATION CONTEXT}

\begin{abstract}
Knowledge and wisdom are the excellence value of cognitive function. Knowledge can be implemented in improving the quality of human life. In the context of the nation's character education, the values of creativity, curiosity and reading habits are the factors of character strengths that build the excellence value of knowledge and wisdom. This study is aimed at examining the structure of the nation's character values which become part of knowledge and wisdom priorities. The study involved 780 senior high school students as the respondents. The findings of the study show that there are three factors of character strength, including creativity, curiosity, and reading habits. These three factors are the factors that can build the excellence value of knowledge and wisdom.
\end{abstract}

Keywords: knowledge and wisdom, national character education

Permalink/DOI: http:// dx.doi.org/10.21831/pep.v22i1.18103 


\section{Pendahuluan}

Isu pendidikan karakter telah muncul sejak tahun 1990-an. Kemunculan isu pendidikan sebagai jalan keluar dari fenomenafenomena yang melibatkan pelajar. Kajian (Ma et al. (2008, p. 319) menyebutkan bahwa salah satu dampak buruk dari fenomena tersebut adalah tingkah laku remaja yang disebabkan oleh rendahnya kekuatan karakter mereka. Melalui kajian Josephson Institute of Ethics (2006, pp. 1-3) diketahui bahwa terdapat $82 \%$ pelajar yang pernah berbohong kepada orang tua dan $60 \%$ pelajar pernah menyontek (cheating) dalam ujian. Lebih lanjut, hasil kajian Hart \& Carlo (2005, p. 224) menyebutkan bahwa $75 \%$ masalah remaja disebabkan oleh rendahnya moral.

Beberapa penelitian menyebutkan kontribusi karakter terhadap keberhasilan pelajar. Park, Peterson, \& Seligman (2006, pp. 96-97) mengutarakan bahwa orang yang optimis walaupun memiliki kompetensi rendah, ternyata lebih berhasil dalam bidang pekerjaan dibandingkan dengan orang yang pesimis tapi memiliki kompetensi tinggi. Begitu juga pelajar yang senantiasa optimis dalam bidang akademik memberi pengaruh terhadap pencapaian belajarnya (Bevel \& Mitchell, 2012, pp. 780-782; Chang, 2011, pp. 491-515).

Pentingnya moral dan karakter generasi muda menyebabkan beberapa negara maju menjadikan pendidikan karakter sebagai program pendidikan kebangsaan. Beberapa negara menggunakan istilah yang berbeda dalam program pendidikan karakter. Di negara-negara barat seperti Amerika Serikat, Kanada dan Inggris pendidikan karakter lebih dikenali dengan istilah pendidikan nilai, sedangkan di sebagian negara Asia pendidikan karakter lebih populer dengan istilah pendidikan moral. Indonesia, awal mulanya menggunakan istilah pendidikan moral kemudian diubah menjadi pendidikan karakter bangsa.

Program pendidikan karakter di Indonesia bermula pada tahun 2010, kemudian dikukuhkan pada Kurikulum 2013. Kementerian Pendidikan Nasional menetapkan program pendidikan karakter bangsa yang mengandung 18 nilai karakter bangsa yang perlu diajarkan dan diterapkan dalam pengajaran dan pendidikan di sekolah. Nilai karakter tersebut adalah keagamaan, kejujuran, toleransi, kedisipinan, kerja keras, kreatif, mandiri, demokratis, memiliki rasa ingin tahu, memiliki semangat kebangsaan, cinta tanah air, menghargai prestasi, bersahabat, cinta perdamaian, gemar membaca, peduli pada alam sekitar, peduli sosial dan bertanggung jawab (Pusat Kurikulum Indonesia, 2009, pp. 9-10). Pendidikan karakter merupakan salah satu metode dalam membina akhlak mulia dan kebiasaan baik bagi pelajar (Schwartz, 2008, pp. 1-23).

Nilai adalah satu set tingkah laku wajar yang mengikuti standar nilai yang dijadikan pedoman oleh individu dan masyarakat sebagai nilai kebaikan (Schwartz, 1994, pp. 19-45). Oleh itu, nilai yang diyakini individu dan masyarakat tersebut menjadi dasar dalam pembentukan karakter seseorang (Lickona, 2012, p. 5). Peterson \& Seligman (2004, pp. 13-14) menghubungkan kekuatan karakter dengan nilai kebajikan karena kebajikan (virtues) dikembangkan berdasarkan kekuatan karakter. Kekuatan karakter berkontribusi dalam mewujudkan potensi dan cita-cita seseorang dalam kehidupan, bermanfaat bagi orang lain, bangsa dan negaranya. Pengetahuan dan kebijaksanaan adalah nilai keutamaan tentang fungsi kognitif. Peterson \& Seligman (2004, p. 29) mengemukakan terdapat lima kekuatan yang meliputi pengetahuan dan kebijaksanaan yaitu kreatif, rasa ingin tahu, mencintai pembelajaran, berfikir kritis dan terbuka serta perspektif.

Dalam konteks teori nilai keutamaan dan kekuatan karakter yang dikemukakan oleh Peterson dan Selignman terdapat persamaan antara nilai karakter bangsa dengan nilai keutamaan dan kekuatan karakter.

Nilai keutamaan merupakan teori yang berpandangan tentang sikap, tingkah laku seseorang. Teori ini tidak memandang perbuatan seseorang itu adil, jujur, atau murah hati. Melainkan teori ini memandangkan apakah seseorang itu berbuat atau bersikap 
adil, jujur atau murah hati (Park, 2004; Park et al., 2006). Isu utama teori keutamaan adalah menjelaskan tentang karakter apa saja yang membuat seseorang sebagai orang baik berdasarkan nilai moral. Menurut Peterson \& Seligman (2004), keutamaan adalah karakteristik utama daripada karakter

Menurut Peterson \& Seligman (2004) keutamaan terbentuk daripada kekuatan karakter. Menurut teori ini, terdapat 24 nilai kekuatan karakter yang membentuk enam nilai keutamaan yaitu kreatif, rasa ingin tahu, berfikir terbuka, mencintai pembelajaran, kebijaksanaan, berani, gigih, integritas, vitalitas, cinta, kebaikan, kecerdasan sosial, kewarganegaraan, keadilan, kepemimpinan, pengampunan, kerendahan hati, kehati-hatian, kontrol diri, apresiasi, rasa syukur, optimisme, humor dan spiritualitas.

Teori keutamaan dan kekuatan karakter menjadi dasar dalam pembuatan instrumen yang mengukur karakter yang disebut Values in Action Inventory of Strengths (VIAIS). Instrumen ini juga digunakan untuk mengukur kekuatan karakter remaja yang disebut Values in Action Inventory Youth (VIA-Y). Instrumen ini sudah banyak digunakan di banyak negara. Oleh itu, teori keutaman dan kekuatan karakter boleh disebut teori yang sudah mapan (established).

Nilai keutamaan pengetahuan dan kebijaksanaan memiliki beberapa kekuatan yakni kreatif, rasa ingin tahu, cinta akan pembelajaran, pikiran yang kritis dan terbuka, dan perspektif. Maka nilai-nilai karakter bangsa yang bisa dikategorikan sebagai nilai keutamaan pengetahuan dan kebijaksanaan adalah kreatif, rasa ingin tahu dan gemar membaca.

Dalam teori kekuatan karakter disebutkan kreatif akan memikirkan keterbaruan dan cara yang produktif untuk melakukan sesuatu (Peterson \& Seligman, 2004). Pembentukan karakter kreatif dapat dicirikan diantaranya penuh inisiatif, banyak ide, dan inovatif.

Kekuatan karakter rasa ingin tahu merupakan ketertarikan, keterbukaan dalam mencari sesuatu yang baru serta motivasi intrinsik seseorang terhadap pengetahuan dan pengalaman baru (Peterson \& Seligman, 2004). Kekuatan ini dapat diidentifikasi dari minat mencari keterbaruan, mencari informasi, dan terbuka terhadap pengalaman baru.

Gemar membaca merupakan kebiasaan yang menjadi perilaku seseorang untuk membaca secara berulang kali dan bisa dilihat seberapa banyak jumlah bacaan yang dibaca, frekuensi membaca serta rata-rata waktu yang dihabiskan membaca (Chettri \& Rout, 2013). Kekuatan karakter gemar membaca dapat diidentifikasi dari kebiasaan meluangkan waktu untuk membaca, mendatangi perpustakaan, mendatangi tempat toko-toko buku bacaan.

Kekuatan karakter di berbagai negara berbeda satu sama lain (Park et al., 2006, pp. 118-129). Hal tersebut disebabkan oleh budaya dan sistem nilai yang dianut oleh suatu bangsa dan negara (Shimai, Otake, Park, Peterson, \& Seligman, 2006, pp. 311322). Kekuatan karakter suatu bangsa mengikuti sistem nilai yang dianut oleh bangsa tersebut, sebagaimana beberapa kajian yang mengadaptasi ke dalam bahasa Jerman (Ruch et al., 2010, pp. 2-12) dan bahasa Hindi (Singh \& Choubisa, 2010, pp. 65-76).

Meskipun telah tersedia instrumen VIA-IS (Value in Action-Inventory Strength) dan VIA-Y (Value in Action-Inventory Strength Youth) yang salah satunya mengukur nilai keutamaan pengetahuan dan kebijaksanaan berserta nilai kekuatannnya, kedua instrumen tersebut belum mengakomodir secara keseluruhan nilai-nilai karakter bangsa Indonesia sesuai dengan program pendidikan karakter bangsa. Oleh itu, perlu dikembangkan sebuah alat untuk mengukur karakter yang sesuai dengan bangsa Indonesia, khususnya yang mengukur nilai karakter bangsa yang meliputi kreatif, rasa ingin tahu, dan gemar membaca.

Penelitian ini bertujuan untuk menentukan validitas instrumen nilai keutamaan pengetahuan dan kebijaksanaan yang mengakomodir nilai-nilai karakter bangsa. Pengujian validitas instrumen bertujuan untuk melihat sejauh manakah suatu instrumen dapat mengukur apa yang semestinya diukur 
(Nunnally \& Bernstein, 1994, p. 83); Pallant, 2016, pp. 90-92). Suatu instrumen dikatakan mempunyai keajegan tinggi apabila mempunyai derajat validitas tinggi dan mengukur apa yang semestinya diukur (Cohen \& Swerdlik, 2009, pp. 106-107).

\section{Metode Penelitian}

Lokasi penelitian dilaksanakan di dua Kabupaten/Kota yaitu Tanah Toraja yang mewakili etnis Tator dan agama Kristen dan Kota Parepare untuk mewakili etnis Bugis dan agama Islam. Responden dalam penelitian ini adalah siswa SMA di Tanah Toraja dan Parepare sebanyak 780 orang dengan perincian 480 perempuan dan 300 laki-laki. Jumlah sampel ini telah memenuhi persyaratan analisis faktor berdasarkan pendapatnya Hair, Anderson, Tatham, \& Black (2010, p. 101) dan Pallant, (2016, p. 178).

Validitas isi dilakukan dengan meminta penilaian pakar psikologi, kewarganega- raan, agama Islam, agama Kristen dan bimbingan konseling. Skala pengukuran item menggunakan adalah skala Likert yaitu 1 untuk "sangat tidak menggambarkan keadaan saya", 2 untuk "tidak menggambarkan keadaan saya", 3 untuk "netral", 4 untuk "menggambarkan keadaan saya" dan 5 untuk "sangat menggambarkan keadaan saya". Item-item yang dikembangkan berkaitan dengan nilai kreatif, rasa ingin tahu, dan gemar membaca.

Data yang terkumpul kemudian dianalisis dengan menggunakan analisis faktor eksploratori (EFA) dan analisis faktor konfirmatori (Confirmatory Factor Analysis/CFA). Analisis faktor eksploratori bertujuan untuk melihat struktur faktor-faktor tertentu (Hair et al., 2010, p. 102). CFA digunakan untuk menentukan kecocokan model hipotesis dengan metode persamaan pemodelan struktur. Analisis dilakukan dengan bantuan software SPSS Versi 23 dan AMOS Versi 20.

Tabel 1. Item-Item Nilai Keutamaan Pengetahuan dan Kebijaksanaan Karakter Bangsa

\begin{tabular}{|c|c|c|c|}
\hline Dimensi & Ciri & Item & Pernyataan \\
\hline \multirow[t]{3}{*}{ Kreatif } & Inovatif & Krea1 & $\begin{array}{l}\text { Saya seringkali memikirkan cara-cara lain yang } \\
\text { berbeda dan baru dalam melakukan sesuatu }\end{array}$ \\
\hline & Banyak idea & Krea2 & Saya orang yang memiliki banyak ide \\
\hline & Inisiatif & Krea3 & $\begin{array}{l}\text { Saya berinisiatif untuk menjawab apa yang } \\
\text { ditanyakan guru kepada murid di kelas }\end{array}$ \\
\hline \multirow[t]{3}{*}{$\begin{array}{l}\text { Rasa Ingin } \\
\text { Tahu }\end{array}$} & $\begin{array}{l}\text { Ketertarikan mencari } \\
\text { sesuatu yang baru }\end{array}$ & RIT1 & $\begin{array}{l}\text { Saya sangat senang mencari materi-materi bahan } \\
\text { pelajaran yang diminta guru }\end{array}$ \\
\hline & $\begin{array}{l}\text { Mencari informasi } \\
\text { tambahan }\end{array}$ & RIT2 & $\begin{array}{l}\text { Sekalipun guru sudah menjelaskan di kelas saya tetap } \\
\text { mencari informasi yang lebih detail }\end{array}$ \\
\hline & $\begin{array}{l}\text { Terbuka terhadap } \\
\text { pengalaman baharu }\end{array}$ & RIT3 & $\begin{array}{l}\text { Saya membuka diri terhadap perkembangan ilmu } \\
\text { baharu }\end{array}$ \\
\hline \multirow[t]{3}{*}{$\begin{array}{l}\text { Gemar } \\
\text { membaca }\end{array}$} & $\begin{array}{l}\text { Menyediakan waktu untuk } \\
\text { membaca }\end{array}$ & GM1 & Saya senantiasa meluangkan waktu untuk membaca \\
\hline & Mengunjungi perpustakaan & GM2 & Saya rutin mendatangi perpustakaan untuk membaca \\
\hline & $\begin{array}{l}\text { Mendatangi toko buku } \\
\text { bacaan }\end{array}$ & GM3 & $\begin{array}{l}\text { Saya menyempatkan diri pergi ke toko buku bacaan } \\
\text { untuk melihat buku-buku bacaan terbaru }\end{array}$ \\
\hline
\end{tabular}

Tabel 2. Analisis Reliabilitas Nilai Alpha Cronbach Untuk Nilai Keutamaan Pengetahuan dan Kebijaksanaan

\begin{tabular}{lccc}
\hline Aspek Nilai Karakter & $\begin{array}{c}\text { Nilai Alpha Cronbach } \\
\text { (Sebelum item } \\
\text { digugurkan) }\end{array}$ & $\begin{array}{c}\text { Jumlah Item yang digugurkan } \\
\text { berdasarkan corrected item total } \\
\text { correlation }<0.30\end{array}$ & $\begin{array}{c}\text { Nilai Alpha Cronbach } \\
\text { (sesudah digugurkan) }\end{array}$ \\
\hline Kreatif & 0,756 & - & - \\
Rasa Ingin Tahu & 0,705 & 2 item & 0.721 \\
Gemar Membaca & 0,596 & 2 item & 0.700 \\
\hline
\end{tabular}




\section{Hasil Penelitian dan Pembahasan}

Sebelum dilakukan analisis faktor eksploratori (EFA) dan analissi faktor konfirmatori (CFA) diperlukan uji persyaratan, salah satunya adalah uji normalitas. Anderson \& Gerbing (1988, pp. 411-423) yang mempersyaratkan data berdistribusi normal pada peringkat univariat adalah diantara +2 hingga -2 . Secara umum nilai $z$ skewness dan kurtosis berdistribusi secara normal. Hair et al. (2010, p. 97) menyebutkan data berdistribusi normal jika semua item dari sebuah instrumen berada pada sebuah garis lurus sudut 45 derajat. Analisis faktor eksploratori pada kajian ini merujuk pada persyaratan yang dikemukakan pakar, sebagaimana Tabel 3. Persyaratan analisi faktor eksploratori mengikut saran (Hair et al. (2010).

Tabel 3. Prasyarat Analisis Faktor Ekxploratori

\begin{tabular}{cll}
\hline Bil & Kriteria & Kriteria \\
\hline 1 & Ujian Kaiser-Meyer-Olkin (KMO) & $0,5-0,7$ \\
2 & Ujian Bartlett's Test of Sphericity & $<0,05$ \\
3 & Anti-image corelation matrix of items & $\geq 0,05$ \\
4 & Nilai variables communalities & $\geq 0,05$ \\
5 & Nilai Loading Factor & $\geq 0,30$ \\
6 & Nilai Eigen Factor & $>1,00$ \\
7 & Persentase Variance & $\geq 60 \%$ \\
\hline
\end{tabular}

Analisis faktor merupakan teknik untuk menentukan validitas konstruk instrumen. Dalam kajian ini peneliti menjalankan analisis faktor untuk setiap aspek nilai dalam karakter bangsa. Untuk tujuan exploratory, penelitian ini menggunakan teknik komponen prinsipal (principal component) orthogonal dengan putaran varimax. Putaran varimax dipilih berdasarkan persyaratan item-item dari konstruk yang berbeda tidak mempunyai korelasi atau hubungan yang baik dan juga metode ini mudah ditafsirkan, sebaliknya putaran oblimax tidak dipilih karena mempersyaratkan item-item atau faktor-faktornya mempunyai korelasi (Pallant, 2016, pp. 182-183). Menurut Pallant (2016, pp. 187-190), putaran varimax bertujuan mengurangi bilangan faktor yang kompleks melalui peningkatan varians yang dimuatkan pada setiap faktor.
Pengkaji juga mengambil nilai pemberat (weight value) 0.6 dalam penilaian bilangan sampel mengikuti kaedah KeiserMeyer-Olkin's (KMO). Menurut Pallant (2016, p. 182), nilai $>0.60$ adalah mencukupi. Hasil penelitian menunjukkan nilai KMO yang diperoleh adalah 0,801 . Hal tersebut berarti telah memenuhi kriteria minimum yang disarankan pakar. Selanjutnya, nilai Barlett's Test of Sphericity adalah signifikan secara statistik $(\mathrm{p}<0,05)$. Hal ini menunjukkan bahwa secara keseluruhan korelasi menggunakan correlation matrix adalah signifikan.

Berikut ini nilai kecukupan sampel mengikut kaidah KMO untuk nilai keutamaan pengetahuan dan kebijaksanaan.

Tabel 4. Kecukupan Sampel Analisis Faktor Eksploratori (Exploration Factor Analysis)

\begin{tabular}{lll}
\hline $\begin{array}{l}\text { Kaiser-Meyer-Olkin Measure of } \\
\text { Sampling Adequacy. }\end{array}$ & 0,799 \\
\hline \multirow{2}{*}{$\begin{array}{l}\text { Bartlett's Test } \\
\text { of Sphericity }\end{array}$} & Df & 1233,008 \\
& Sig. & 36 \\
\end{tabular}

Tabel 5. Matriks Komponen dengan Putaran (Varimax Variabel) Nilai Keutamaan Pengetahuan dan Kebijaksanaan

\begin{tabular}{lccc}
\hline Ciri-Ciri & Faktor 1 & Faktor 2 & Faktor 3 \\
\hline Inovatif & & & 0,791 \\
Banyak idea & & & 0,850 \\
Inisiatif & & & 0,792 \\
Ketertarikan & 0,772 & & \\
Mencari informasi & 0,619 & & \\
Terbuka dengan & 0,672 & & \\
pengalaman & & & \\
Menyediakan waktu & & 0,728 & \\
untuk membaca & & & \\
Mengunjungi & & 0,640 & \\
perpustakaan & & & \\
Mengunjungi toko & & 0,742 & \\
buku bacaan & & & \\
Eigen & 2,304 & 2,205 & 1,979 \\
\% of Variance & 25,601 & 24,497 & 21,991 \\
Cumulative \% & 25,601 & 50.099 & 72,090 \\
Nilai Karakter & Gemar & Rasa & Ingin \\
Bangsa & Kembacatif & Tahu & \\
\hline
\end{tabular}

Nilai Keutamaan Pengetabuan dan Kebijaksanaani ... - 
Tabel 5 menunjukkan pembentukan faktor nilai keutamaan pengetahuan dan kebijaksanaan dalam konteks pendidikan karakter bangsa. Gemar membaca adalah faktor pertama, rasa ingin tahu sebagai faktor kedua dan kreatif sebagai faktor ketiga.

Diagram scree plot pada Gambar 1 menunjukkan bagaimana kecenderungan penurunan nilai eigen (eigenvalues) yang dipakai untuk menentukan banyaknya faktor yang dipakai.

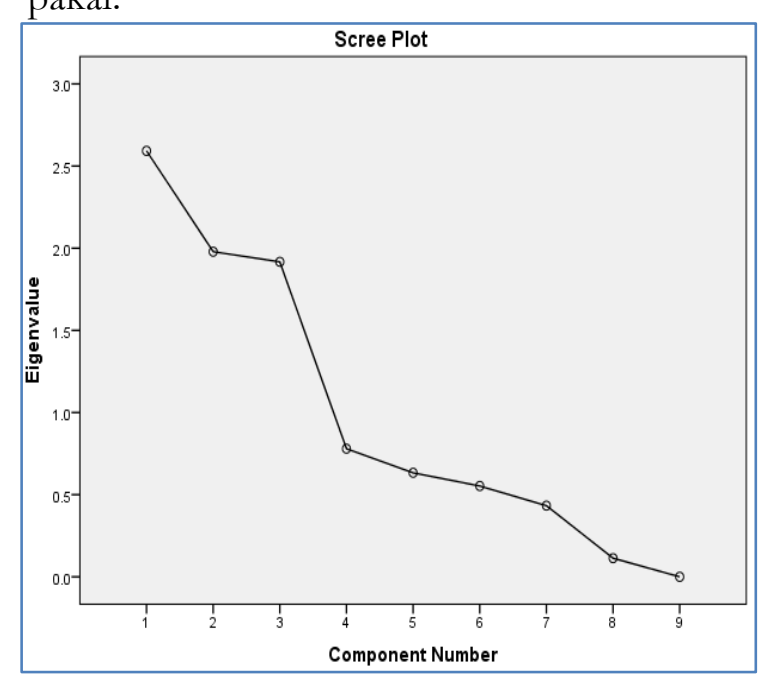

Gambar 1. Scree plot pada ujian pengesahan

Mengacu pada pendapat Tabachnick \& Fidell (2013, p. 709) suatu model dikatakan memenuhi kriteria model yang sesuai jika memenuhi sekurang-kurangnya satu indeks model fit. Indeks model fit yang dimaksud adalah tes Chi-square $\left(\chi^{2}\right)$, Root Mean Square of Error Approximation (RMSEA, GFI (Goodness of Fit Index), AGFI (Adjusted Goodness of Fit Index), CFI dan TLI. Untuk mencapai kesesuaian model, nilai relatif Chi-square semestinya kurang dari 5,0 sedangkan CFI dan TLI lebih dari 0,9. Untuk nilai RMSEA hendaknya kurang dari 0,08 (Schumacker \& Lomax, 2004, p. 261). Gambar 2 menunjukkan model CFA pada penelitian ini.

Pada tabel 6 ditunjukkan kriteria model fit CFA nilai keutamaan pengetahuan dan kebijaksanaan pada karakter bangsa.

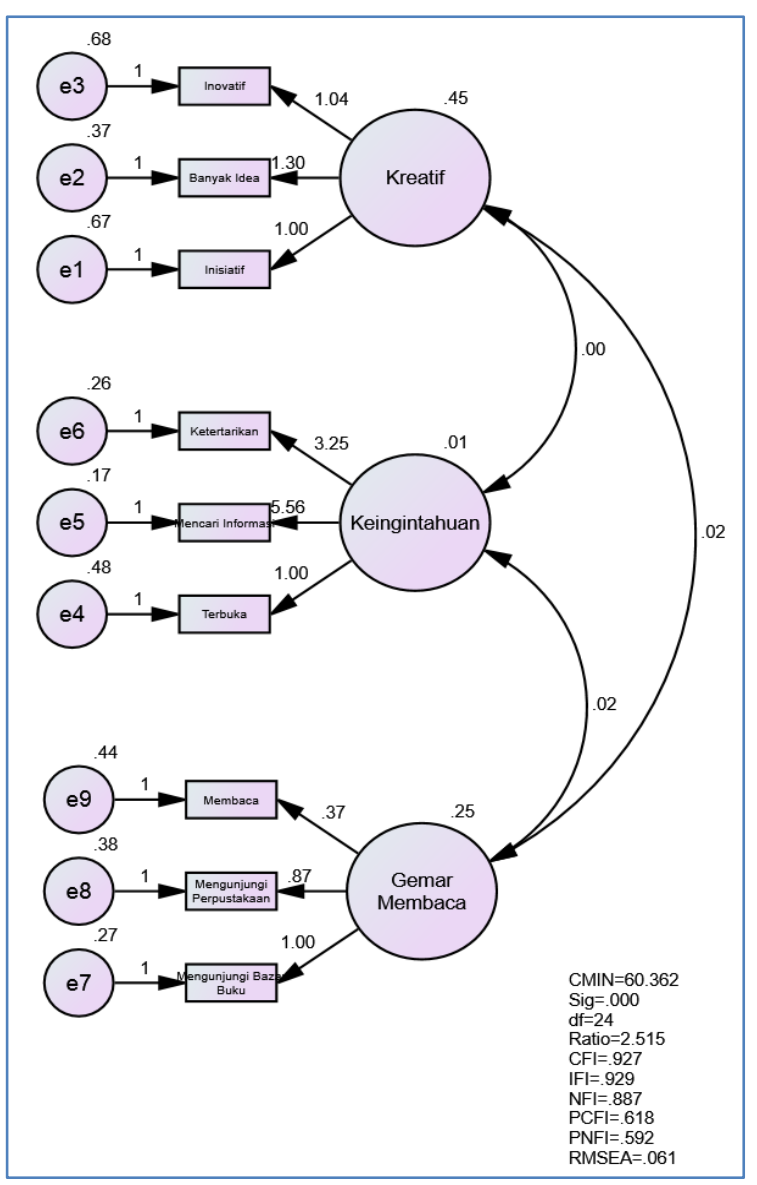

Gambar 2. Model CFA Nilai

Keutamaan Pengetahuan dan

Kebijaksanaan Karakter Bangsa

Tabel 6. Analisis Faktor Konfirmatori (Confirmatory Factor Analysis)

(IPKB

\begin{tabular}{lccl}
\hline $\begin{array}{l}\text { Goodness of } \\
\text { fit Indexs }\end{array}$ & $\begin{array}{c}\text { Cut off } \\
\text { Value }\end{array}$ & $\begin{array}{c}\text { Hasil } \\
\text { Model }\end{array}$ & Keterangan \\
\hline$\chi^{2}$ - Chi square & - & 60,362 & \\
Probability & $\geq 0,05$ & 0,000 & Kurang Baik \\
RMSEA & $\leq 0,08$ & 0,061 & Baik \\
CFI & $\geq 0,90$ & 0,927 & Baik \\
AGFI & $\geq 0,90$ & 0,943 & Baik \\
TLI & $\geq 0,90$ & 0,891 & Kurang Baik \\
GFI & $\geq 0,90$ & 0,970 & Baik \\
\hline
\end{tabular}

Tabel 6 menunjukan hasil analisis faktor konfirmatori nilai keutamaan pengetahuan dan kebijaksanaan. Nilai indeks model fit adalah bersamaan dengan $p=0,000$, nilai relatif tes Chi-square secara bersamaan adalah 60.362, nilai 0,927 untuk CFI, nilai 0,943 untuk AGFI, nilai 0,891 untuk TLI, 
nilai 0,970 untuk GFI dan 0,061 untuk RMSEA.

Tabel 7. Validitas Konstruk Nilai Keutamaan Pengetahuan dan Kebijaksanaan Karakter Bangsa

\begin{tabular}{llcc}
\hline Dimensi & Item & AVE & CR \\
\hline Kreatif & Krea1 & 0,701 & 0,859 \\
& Krea2 & & \\
& Krea3 & & \\
Keingintahuan & RIT1 & 0,501 & 0,782 \\
& RIT2 & & \\
& RIT3 & & \\
Gemar Membaca & GM1 & 0,515 & 0,790 \\
& GM2 & & \\
& GM3 & & \\
\hline
\end{tabular}

Keterangan:

AVE $=$ Average Variance Extracted $\mathrm{CR}=$ Composite Reliability

Menurut Hair et al. (2010) Hair et al. (2010), reliabilitas perlu memenuhi tiga kriteria yaitu reliabilitas internal yang ditentukan oleh nilai Alpha Cronbach lebih dari 0,70 , nilai reliabilitas konstruk atau composite reliability (CR) lebih dari 0,60 dan nilai average variance extracted (AVE) melebihi 0,40 sebagaimana ditunjukkan pada Tabel 6 .

Tabel 7 menunjukkan semua konstruk telah memenuhi kriteria reliabilitas yaitu nilai AVE lebih 0.40 dan nilai CR lebih dari 0,70 . Ini menunjukkan bahwa model pengukuran tahap validitas dan reliabilitas mempunyai kriteria yang baik.

Tujuan penelitian ini adalah untuk memeriksa struktur nilai-nilai karakter bangsa yang menjadi bagian dari nilai keutamaan pengetahuan dan kebijaksanaan. Penelitian ini telah berhasil membuktikan bahwa terdapat tiga faktor nilai karakter bangsa yakni, kreatif, rasa ingin tahu dan gemar membaca yang dapat menjadi bagian dari pembentuk nilai keutamaan pengetahuan dan kebijaksanaan.

Berdasarkan teori keutamaan dan kekuatan karakter Peterson dan Seligman, nilai keutamaan pengetahuan dan kebijaksanaan terbentuk dari kekuatan karakter kreatif, rasa ingin tahu, mencintai pembelajaran, pikir- an terbuka dan presfektif. Persamaan kekuatan karakter untuk nilai keutamaan pengetahuan dan kebijaksanaan dalam konteks pendidikan karakter bangsa adalah kreatif, rasa ingin tahu dan gemar membaca.

Penelitian ini serupa dengan beberapa kajian yang menunjukkan bahwa kreatif, rasa ingin tahu, mencintai pembelajaran bagian dari nilai keutamaan pengetahuan dan kebijaksanaan (Ruch \& Proyer, 2015, pp. 2-12). Kajian Macdonald, Bore, \& Munro (2008, pp. 787-799) memasukkan kekuatan karakter kreatif, rasa ingin tahu, mencintai pembelajaran ke dalam faktor intelektual dengan nilai loading factor masingmasing -0,78, -0,61 dan -0,60. Kajian Singh \& Choubisa (2010, pp. 325-332), LittmanOvadia \& Lavy (2012, pp. 41-50), dan Ruch et al. (2010, pp. 138-149) memasukkan ke dalam faktor Intellectual Strengths. Pembentukan kekuatan karakter kreatif, rasa ingin tahu dan gemar membaca dalam nilai keutamaan kebijaksanaan dan pengetahuan sesuai dengan Peterson dan Selignman.

\section{Simpulan}

Berdasarkan hasil penelitian dan pembahasan dapat disimpulkan bawa dalam nilai keutamaan kebijaksanaan dan pengetahuan konteks pendidikan karakter terbentuk tiga nilai kekuatan karakter yaitu nilai karakter gemar membaca, rasa ingin tahu dan kreatif. Item-item dalam kajian ini telah sesuai dengan ciri-ciri yang dikemukakan dalam pengembangan instrumen ini.

\section{Daftar Pustaka}

Anderson, J. C., \& Gerbing, D. W. (1988). Structural equation modeling in practice: A review and recommended two-step approach. Psychological Bulletin, 103(3), 411-423.

Bevel, R. K., \& Mitchell, R. M. (2012). The effects of academic optimism on elementary reading achievement. Journal of Educational Administration, 50(6), 773-787. https://doi.org/10.1108/09578231211 


\section{5}

Chang, I.-H. (2011). A study of the relationships between distributed leadership, teacher academic optimism and student achievement in Taiwanese elementary schools. School Leadership \& Management, 31(5), 491-515.

https://doi.org/10.1080/13632434.20 11.614945

Chettri, K., \& Rout, S. K. (2013). Reading habits - an overview. IOSR Journal Of Humanities And Social Science (IOSRJHSS), 14(6). Retrieved from http://www.iosrjournals.org/iosrjhss/papers/Vol14issue6/C01461317.pdf

Cohen, R. J., \& Swerdlik, M. (2009). Psychological testing and assessment: an introduction to tests and measurement (7th ed.). USA: McGraw-Hill.

Hair, J. F., Anderson, R. E., Tatham, R. L., \& Black, W. C. (2010). Multivariate data analysis (4th ed.). New Jersey: Prentice Hall.

Hart, D., \& Carlo, G. (2005). Moral development in adolescence. Journal of Research on Adolescence, 15(3), 223-233. https://doi.org/10.1111/j.15327795.2005.00094.x

Josephson Institute of Ethics. (2006). The ethics of American youth. Retrieved from http://www.josephsoninstitute.org

Lickona, T. (2012). Character Matters: Persoalan Karakter, (terj. Juma Wadu Wamaungu \& Jean Antunes Rudolf Zien dan Editor Uyu $W$ abyuddin dan Suryani). Jakarta: Bumi Aksara.

Littman-Ovadia, H., \& Lavy, S. (2012). Character strengths in Israel. European Journal of Psychological Assessment, 28(1), 41-50. https://doi.org/10.1027/10155759/a000089

Ma, M., Kibler, J. L., Dollar, K. M., Sly, K., Samuels, D., Benford, M. W., ... Wiley, F. (2008). The relationship of character strengths to sexual behaviors and related risks among African American adolescents. International Journal of Behavioral Medicine, 15(4), 319327.

https://doi.org/10.1080/10705500802 365573

Macdonald, C., Bore, M., \& Munro, D. (2008). Values in action scale and the Big 5: An empirical indication of structure. Journal of Research in Personality, 42(4), 787-799. https://doi.org/10.1016/j.jrp.2007.10. 003

Nunnally, J. C., \& Bernstein, I. H. (1994). Psychometric theory (3rd ed.). New York: McGraw Hill.

Pallant, J. (2016). SPSS survival manual: a step by step guide to data analysis using IBM SPSS. Sydney: Allen \& Unwin.

Park, N. (2004). Character strengths and positive youth development. The ANNALS of the American Academy of Political and Social Science, 591(1), 40-54. https://doi.org/10.1177/00027162032 60079

Park, N., Peterson, C., \& Seligman, M. E. P. (2006). Character strengths in fiftyfour nations and the fifty US States. The Journal of Positive Psychology, 1(3), 118-129.

Peterson, C., \& Seligman, M. E. P. (2004). Character strengths and virtues: a bandbook and classification. Oxford: Oxford University Press.

Pusat Kurikulum Indonesia. (2009). Pengembangan dan pendidikan budaya karakter bangsa. Jakarta: Kementerian Pendidikan dan Kebudayaan republik Indonesia.

Ruch, W., \& Proyer, R. T. (2015). Mapping strengths into virtues: the relation of the 24 VIA-strengths to six ubiquitous virtues. Frontiers in Psychology, 6. https://doi.org/10.3389/ fpsyg.2015.0 0460 
Ruch, W., Proyer, R. T., Harzer, C., Park, N., Peterson, C., \& Seligman, M. E. P. (2010). Values in action inventory of strengths (VIA-IS). Journal of Individual Differences, 31(3), 138-149. https://doi.org/10.1027/16140001/a000022

Schumacker, R., \& Lomax, R. (2004). A beginner's guide to structural equation modeling (2nd ed.). Mahwah, NJ: Lawrence Erlbaum.

Schwartz, M. J. (2008). Introduction to character education and effective principles. In M. J. Schwartz (Ed.), Effective character education: A guidebook for future educators (pp. 1-23). New York: McGraw-Hill.

Schwartz, S. H. (1994). Are there universal aspects in the structure and contents of human values? Journal of Social Issues,
50(4), 19-45.

https://doi.org/10.1111/j.1540-

4560.1994.tb01196.x

Shimai, S., Otake, K., Park, N., Peterson, C., \& Seligman, M. E. P. (2006).

Convergence of character strengths in American and Japanese young adults. Journal of Happiness Studies, 7(3), 311322. https://doi.org/10.1007/s10902005-3647-7

Singh, K., \& Choubisa, R. (2010). Empirical validation of values in action-inventory of strengths (VIA-IS) in Indian context. Psychological Studies, 55(2), 151158. https://doi.org/10.1007/s12646010-0015-4

Tabachnick, B. G., \& Fidell, L. S. (2013). Using multivariate statistics (6th ed.). Boston: Pearson \& Bacon. 